\title{
Maritimibacter alkaliphilus gen. nov., sp. nov., a genome-sequenced marine bacterium of the Roseobacter clade in the order Rhodobacterales
}

Correspondence Jang-Cheon Cho chojc@inha.ac.kr

\author{
Kiyoung Lee, ${ }^{1}$ Yoe-Jin Choo, ${ }^{1}$ Stephen J. Giovannoni ${ }^{2}$ \\ and Jang-Cheon $\mathrm{Cho}^{1}$ \\ 1Division of Biology and Ocean Sciences, Inha University, Incheon 402-751, Republic of Korea \\ ${ }^{2}$ Department of Microbiology, Oregon State University, Corvallis, OR 97331, USA
}

\begin{abstract}
A Gram-negative, chemoheterotrophic, strictly aerobic, alkaliphilic, rod-shaped marine bacterium, designated HTCC2654 ${ }^{\top}$, was isolated from the western Sargasso Sea by using a dilution-toextinction culturing method. Phylogenetic analyses based on 16S rRNA gene sequences showed that strain $\mathrm{HTCC} 2654^{\top}$ belonged to the Roseobacter clade of the order Rhodobacterales. The 16S rRNA gene sequence similarity of the strain with respect to other members of the Roseobacter clade ranged from 90.4 to $95.1 \%$. In the phylogenetic analyses, the strain formed an independent phyletic line and could not be assigned to any other known genera of the Rhodobacterales. The DNA G $+\mathrm{C}$ content of strain $\mathrm{HTCC}_{2} 654^{\top}$ was $61.7 \mathrm{~mol} \%$ by HPLC and $64.1 \mathrm{~mol} \%$ from genome sequences. The predominant constituents of the cellular fatty acids were $\mathrm{C}_{16: 0} 2-\mathrm{OH}(27.3 \%), 11$-methyl $\mathrm{C}_{18: 1} \omega 7 c(19.6 \%)$ and $\mathrm{C}_{18: 1} \omega 7 c(17.3 \%)$, and the major polar lipids were phosphatidylethanolamine, phosphatidylglycerol and phosphatidylcholine, which served to differentiate the strain from other members of the Roseobacter clade. On the basis of the taxonomic data obtained in this study, strain $\mathrm{HTCC}_{2} 654^{\top}$ represents a novel genus and species, for which the name Maritimibacter alkaliphilus gen. nov., sp. nov. is proposed. The type strain is $\mathrm{HTCC}^{2654^{\top}}\left(=\mathrm{KCCM} 42376^{\top}=\mathrm{NBRC} 102057^{\top}\right)$.
\end{abstract}

The Roseobacter clade (Giovannoni \& Rappé, 2000) in the order Rhodobacterales encompasses diverse members of marine alphaproteobacteria. Both culture-independent and culture-dependent surveys have shown that this clade is one of the most abundant 16S rRNA gene lineages in marine ecosystems. Since 2002, cultivation approaches involving high-throughput culturing using a dilution-to-extinction method (Button et al., 1993; Connon \& Giovannoni, 2002) have allowed many hitherto uncultured members of the Roseobacter clade to be cultured. Among the isolates in the Roseobacter clade that were obtained by high-throughput

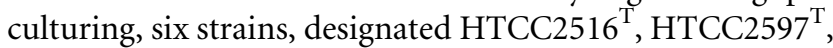
HTCC $2601^{\mathrm{T}}$, HTCC2150, HTCC2255 and HTCC2654 ${ }^{\mathrm{T}}$, have been subjected to full genome shotgun sequencing (http://www.moore.org/microgenome). The drafts for their whole genome sequences have been deposited in the GenBank database. The binomial names of strains HTCC2516 ${ }^{\mathrm{T}}, \mathrm{HTCC} 597^{\mathrm{T}}$ and HTCC $2601^{\mathrm{T}}$ have been validly published, on the basis of polyphasic taxonomy, as

The GenBank/EMBL/DDBJ accession number for the $16 \mathrm{~S}$ rRNA gene sequence of strain $\mathrm{HTCC}^{2654^{\top}}$ is DO915443.

A thin-layer chromatogram indicating the polar lipids of strain $\mathrm{HTCC} 2654^{\top}$ and a transmission electron micrograph of a cell of strain $\mathrm{HTCC} 2654^{\top}$ are available with the online version of this paper.
Oceanicola granulosus (Cho \& Giovannoni, 2004), Oceanicola batsensis (Cho \& Giovannoni, 2004) and Pelagibaca bermudensis (Cho \& Giovannoni, 2006), respectively. Strains HTCC2150 and HTCC2255, isolated from the Oregon coast of the USA, do not form colonies on standard solid agar plates (such as marine agar 2216), which made polyphasic characterization difficult. Strain HTCC $2654^{\mathrm{T}}$, isolated from the western Sargasso Sea (Atlantic Ocean) grew well on marine agar 2216 (MA; Difco), and thus here we can report on the characterization of this strain. On the basis of our taxonomic evaluations, strain HTCC $2654^{\mathrm{T}}$ represents a novel genus and species in the Roseobacter clade.

The extinction culture of strain HTCC $2654^{\mathrm{T}}$ was obtained using previously described high-throughput culturing approaches (Cho \& Giovannoni, 2003; Connon \& Giovannoni, 2002). The strain was subsequently purified as single colonies on $\mathrm{MA}$ after incubation at $25^{\circ} \mathrm{C}$ for 4 days, and was stored as $10 \%(\mathrm{v} / \mathrm{v})$ glycerol suspensions in liquid nitrogen and in a deep-freezer at $-86^{\circ} \mathrm{C}$. Unless stated otherwise, the strain was grown routinely on MA at $30^{\circ} \mathrm{C}$ for characterization studies.

DNA extraction, $16 \mathrm{~S}$ rRNA gene amplification, and sequencing of the PCR products were performed as described previously (Cho \& Giovannoni, 2003). Almost-complete 
16S rRNA gene sequences (1407 bp) of strain HTCC $2654^{\mathrm{T}}$ were obtained and used for phylogenetic analyses. Comparisons of the 16S rRNA gene sequence of strain HTCC $2654^{\mathrm{T}}$ with those held in GenBank and Ribosomal Database Project II (Cole et al., 2005) showed that the strain belonged to the order Rhodobacterales of the class Alphaproteobacteria. To determine the phylogenetic relationships between strain HTCC $2654^{\mathrm{T}}$ and other members of the Roseobacter clade, phylogenetic inferences were performed with the ARB software package (Ludwig et al., 2004) and PAUP ${ }^{*} 4.0$ beta 10 (Swofford, 2002). Reference sequences comprising more than $1300 \mathrm{bp}$ were included in the phylogenetic analysis, and 1185 unambiguously aligned nucleotide positions were used. Comparisons with the ARB database showed that strain HTCC $2654^{\mathrm{T}}$ was distantly related to the members of the Roseobacter clade. The 16S rRNA gene sequence similarity of the strain with respect to species of the Rhodobacterales ranged from 90.4 to $95.1 \%$. The most closely related recognized species were Roseovarius crassostreae ( $95.1 \%$ sequence similarity), followed by O. batsensis ( $94.5 \%)$, Roseovarius tolerans (94.5\%), Thalassobius mediterraneus (94.4\%), Jannaschia rubra (94.1\%) and Jannaschia cystaugens (94.1\%). To clarify the phylogenetic position of the strain, phylogenetic trees were generated by using the neighbour-joining (Saitou \& Nei, 1987), maximum-parsimony (Fitch, 1971) and maximum-likelihood (Felsenstein, 1981) approaches. The robustness of the neighbour-joining and maximumparsimony trees was evaluated by performing bootstrap analyses based on 1000 resamplings. In all of the phylogenetic trees, strain HTCC $2654^{\mathrm{T}}$ failed to form any robust phylogenetic clades with members of the Roseobacter clade, but did form an independent phyletic line (Fig. 1). Although the genera Roseovarius, Oceanicola, Thalassobius and Jannaschia were related to strain HTCC $2654^{\mathrm{T}}$ with 94.1-95.1\% 16S rRNA gene sequence similarity, strain HTCC2 $254^{\mathrm{T}}$ was not phylogenetically associated with any other genera of the Roseobacter clade. The most closely related species (on the basis of sequence similarity to strain HTCC $2654^{\mathrm{T}}$ ), i.e. R. crassostreae, was phylogenetically separated from the three other Roseovarius species (Fig. 1), suggesting a need for the reclassification of $R$. crassostreae to another taxon. The distant relationship between strain HTCC $2654^{\mathrm{T}}$ and members of the order Rhodobacterales from the above phylogenetic analyses suggested that this strain represented a novel genus within the order Rhodobacterales in the class Alphaproteobacteria.

The genome size and DNA $\mathrm{G}+\mathrm{C}$ content of strain HTCC $2654^{\mathrm{T}}$ were computed from the draft genome sequence (GenBank accession number AAMT00000000), consisting of six contigs, which was prepared by the J. Craig Venter Research Institute (Rockville, MD, USA). In addition, the DNA $\mathrm{G}+\mathrm{C}$ content was analysed by using HPLC with a Discovery C18 column $(5 \mu \mathrm{m}, 15 \mathrm{~cm} \times$ $4.6 \mathrm{~mm}$; Supelco) (Mesbah et al., 1989). Respiratory quinones were investigated, using reversed-phase HPLC, by the

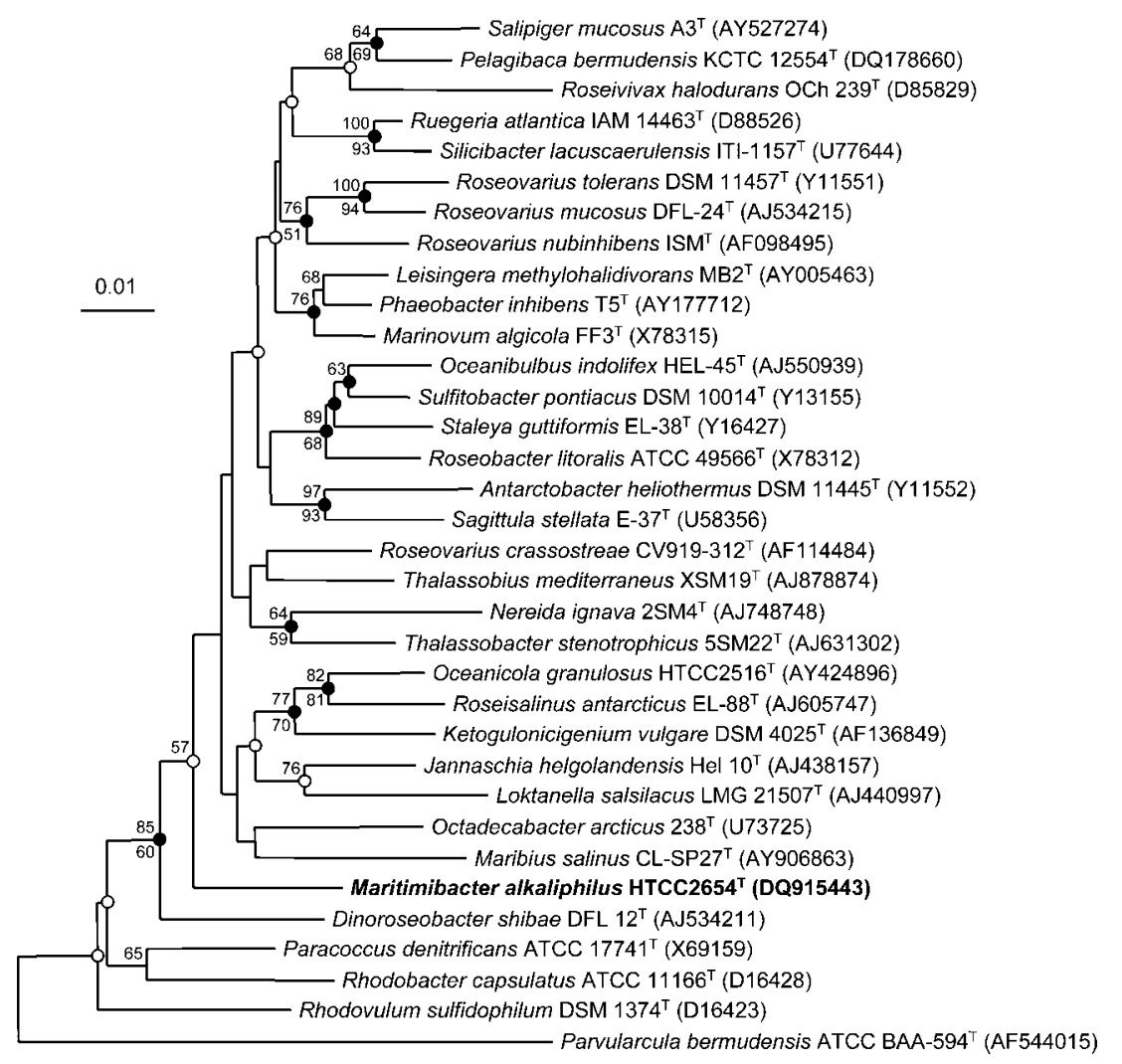

Fig. 1. Neighbour-joining phylogenetic tree, based on 16S rRNA gene sequences, showing the relationships between strain HTCC2654 $4^{\top}$ and representatives of the order Rhodobacterales. Bootstrap percentages (above $50 \%$ ) from both the neighbour-joining approach (above the nodes) and the maximum-parsimony approach (below the nodes) are shown. Filled and open circles indicate nodes recovered reproducibly by all treeing methods or by two treeing methods, respectively. Bar, 0.01 substitutions per nucleotide position. 
Korean Culture Center of Microorganisms (Seoul, Korea). Cellular fatty acid methyl esters were prepared from a culture grown on $\mathrm{MA}$ at $30^{\circ} \mathrm{C}$ for 3 days, and analysed, according to the instructions of the Microbial Identification System (MIDI), by the Center. The estimated genome size, based on genome sequencing data, was approximately $4.5 \mathrm{mbp}$, coding for 4757 open reading frames. The DNA $\mathrm{G}+\mathrm{C}$ content of strain HTCC $2654^{\mathrm{T}}$ was $64.1 \mathrm{~mol} \%$ from genome sequences and $61.7 \mathrm{~mol} \%$ with the HPLC method. The only respiratory quinone detected was Q-10, which is a typical quinone of members of the Roseobacter clade. Polar lipids were extracted with chloroform/methanol $/ 0.3 \% \mathrm{NaCl}$ $(90: 100: 30$, by vol.), purified and then identified as described by Minnikin et al. (1984). The major polar lipids found in strain HTCC $2654^{\mathrm{T}}$ were phosphatidylcholine, phosphatidylethanolamine and phosphatidylglycerol (see Supplementary Fig. S1 available in IJSEM Online), the profile being similar to those of the genera Ruegeria and Jannaschia, except that they lack diphosphatidylglycerol. The major fatty acids found in strain HTCC2654 ${ }^{\mathrm{T}}$, i.e. $\mathrm{C}_{16: 0}$ 2-OH (27.3\%), 11-methyl $\mathrm{C}_{18: 1} \omega 7 c$ (19.6\%), $\mathrm{C}_{18: 1} \omega 7 c$ $(17.3 \%)$ and $\mathrm{C}_{16: 0}(15.3 \%)$, were different with respect to other members of the Roseobacter clade (Table 1). Characteristics that serve to differentiate strain $\mathrm{HTCC}_{2} 654^{\mathrm{T}}$ from other species of the Roseobacter clade are listed in Table 1.

Phenotypic characterization was carried out as described in previous studies (Cho \& Giovannoni, 2004; Smibert \& Krieg, 1994), at $30^{\circ} \mathrm{C}$ with MA as the basal medium. Cell morphology was examined by using energy-filtering transmission electron microscopy (LIBLA120; Carl Zeiss) and phase-contrast and epifluorescence microscopy (Nikon 80i; Nikon). The presence of poly- $\beta$-hydroxyalkanoate granules was checked for by using epifluorescence microscopy after staining of the cells with Nile blue A (Ostle \& Holt, 1982). Anaerobic growth was tested on MA at $30^{\circ} \mathrm{C}$ using both the MGC anaerobic system and AnaeroPACK Anaero (Mitsubishi Gas Chemical Company). Colony morphology, size and colour were examined using cultures grown aerobically on MA at $30^{\circ} \mathrm{C}$ for 3 days. For detecting bacteriochlorophyll $a$ and carotenoids, pigments of strain HTCC2654 ${ }^{\mathrm{T}}$ were extracted with acetone/methanol $(1: 1$, $\mathrm{v} / \mathrm{v})$ and absorption spectra were determined using a scanning UV/visible spectrophotometer (Optizen 2120UV; Mechasis). The $\mathrm{pH}$ range and optimum were examined at $\mathrm{pH}$ values in the range 4.0-12.0. The $\mathrm{pH}$ was adjusted with $0.1 \mathrm{M} \mathrm{HCl}$ and $0.1 \mathrm{M} \mathrm{NaOH}$. The $\mathrm{NaCl}$ concentration range and optimum for growth were determined in a medium that contained the following $\left(1^{-1}\right): 1.0 \mathrm{~g} \mathrm{MgCl}_{2} \cdot 6 \mathrm{H}_{2} \mathrm{O}, 5.0 \mathrm{~g}$ $\mathrm{MgSO}_{4} .7 \mathrm{H}_{2} \mathrm{O}, 0.7 \mathrm{~g} \mathrm{KCl}, 0.5 \mathrm{~g} \mathrm{NH}_{4} \mathrm{Cl}, 0.27 \mathrm{~g} \mathrm{KH}_{2} \mathrm{PO}_{4}$, $0.15 \mathrm{~g} \mathrm{CaCl}_{2} .2 \mathrm{H}_{2} \mathrm{O}, 0.1 \mathrm{~g} \mathrm{KBr}, 0.04 \mathrm{~g} \mathrm{SrCl}_{2} .6 \mathrm{H}_{2} \mathrm{O}, 0.025 \mathrm{~g}$ $\mathrm{H}_{3} \mathrm{BO}_{3}, 5.0$ g peptone and 1.0 g yeast extract ( $\mathrm{pH}$ 8.0) with $0-20 \% \mathrm{NaCl}(\mathrm{w} / \mathrm{v})$. The catalase test was performed by adding $3.0 \%$ hydrogen peroxide to fresh colonies, and oxidase activity was determined using Kovács' solution (Kovács, 1956). Biochemical tests and carbon-source utilization tests were carried out on API 20NE, API ZYM (both from bioMérieux) and Biolog GN2 microplates, with artificial seawater $\left(\mathrm{l}^{-1}: 25.0 \mathrm{~g} \mathrm{NaCl}, 1.0 \mathrm{~g} \mathrm{MgCl}_{2} \cdot 6 \mathrm{H}_{2} \mathrm{O}\right.$, $5.0 \mathrm{~g} \mathrm{MgSO}_{4} \cdot 7 \mathrm{H}_{2} \mathrm{O}, 0.7 \mathrm{~g} \mathrm{KCl}, 0.15 \mathrm{~g} \mathrm{CaCl}_{2} \cdot 2 \mathrm{H}_{2} \mathrm{O}, 0.5 \mathrm{~g}$ $\mathrm{NH}_{4} \mathrm{Cl}, 0.1 \mathrm{~g} \mathrm{KBr}, 0.27 \mathrm{~g} \mathrm{KH}_{2} \mathrm{PO}_{4}, 0.04 \mathrm{~g} \mathrm{SrCl}_{2} .6 \mathrm{H}_{2} \mathrm{O}$ and $0.025 \mathrm{~g} \mathrm{H}_{3} \mathrm{BO}_{3}$ ), according to the manufacturers' instructions. The following antimicrobial agents were tested: ampicillin $(10 \mu \mathrm{g})$, chloramphenicol $(25 \mu \mathrm{g})$, erythromycin $(15 \mu \mathrm{g})$, gentamicin $(10 \mu \mathrm{g})$, kanamycin $(30 \mu \mathrm{g})$, penicillin $\mathrm{G}(10 \mu \mathrm{g})$, rifampicin $(50 \mu \mathrm{g})$, streptomycin $(10 \mu \mathrm{g})$, tetracycline $(30 \mu \mathrm{g})$ and vancomycin $(30 \mu \mathrm{g})$.

Morphological, physiological, and biochemical characteristics of strain HTCC $2654^{\mathrm{T}}$ are listed in the genus and species descriptions and in Table 1 . The strain was found to be Gram-negative, chemoheterotrophic, strictly aerobic, slightly alkaliphilic, to require $\mathrm{NaCl}$ for growth and to consist of non-motile, rod-shaped cells (see Supplementary Fig. S2 available in IJSEM Online). The strain did not produce bacteriochlorophyll $a$ or poly- $\beta$-hydroxyalkanoate granules. These phenotypic characteristics, together with chemotaxonomic properties, serve to differentiate the strain from related genera of the Roseobacter clade (Table 1). The most important chemotaxonomic property that differentiates strain HTCC $2654^{\mathrm{T}}$ from other members of the clade is the cellular fatty acid composition. Generally, the most dominant cellular fatty acid detected in members of the Roseobacter clade is cis-7-octadecenoic acid, with a content of approximately $60-80 \%$ (Martens et al., 2006). The percentage of cis-7-octadecenoic acid in strain HTCC $2654^{\mathrm{T}}$ was only $17.3 \%$, whereas hydroxyl $\left(\mathrm{C}_{16: 0} 2-\mathrm{OH}, 27.3 \%\right)$ and methyl (11-methyl $\left.\mathrm{C}_{18: 1} \omega 7 c, 19.6 \%\right)$ fatty acids were abundant. On the basis of phenotypic and chemotaxonomic traits, strain HTCC2654 ${ }^{\mathrm{T}}$ cannot be characterized as a member of any of the known genera within the Roseobacter clade.

The combined phenotypic, chemotaxonomic, and phylogenetic evidence conclusively demonstrates that strain HTCC $2654^{\mathrm{T}}$ represents a novel genus and species in the Roseobacter clade (order Rhodobacterales), for which the name Maritimibacter alkaliphilus gen. nov., sp. nov. is proposed.

\section{Description of Maritimibacter gen. nov.}

Maritimibacter (Ma.ri.ti'mi.bac'ter. L. adj. maritimus of the sea; N.L. masc. n. bacter a rod, bacterium; N.L. masc. n. Maritimibacter a rod-shaped bacterium of the sea).

Cells are Gram-negative, non-motile, strictly aerobic rods that are 1.4-2.5 $\mu \mathrm{m}$ long and 0.7-0.9 $\mu \mathrm{m}$ wide. Carotenoid pigments and bacteriochlorophyll $a$ are not found. Do not produce exopolysaccharides or poly- $\beta$-hydroxyalkanoate granules. Chemoheterotrophic and require $\mathrm{NaCl}$ for growth. The predominant fatty acids are $\mathrm{C}_{16: 0} 2-\mathrm{OH}, 11-$ methyl $\mathrm{C}_{18: 1} \omega 7 c$ and $\mathrm{C}_{18: 1} \omega 7 c$. The only respiratory quinone detected is Q-10. Phosphatidylcholine, phosphatidylethanolamine and phosphatidylglycerol are the major polar lipids. The genus is phylogenetically affiliated to the 
Table 1. Differential characteristics of strain $\mathrm{HTCC} 2654^{\top}$ and other related taxa within the Roseobacter clade

Taxa: 1, strain HTCC2654 ${ }^{\mathrm{T}}$; 2, R. crassostreae (data from Boettcher et al., 2005); 3, Roseovarius (Biebl et al., 2005; González et al., 2003; Labrenz et al., 1999); 4, Oceanicola (Cho \& Giovannoni, 2004; Gu et al., 2007); 5, Thalassobius (Arahal et al., 2005; Rüger \& Höfle, 1992); 6, Jannaschia (Adachi et al., 2004; Choi et al., 2006; Macián et al., 2005; Wagner-Döbler et al., 2003). +, Positive reaction; -, negative reaction; $\mathrm{V}$, variable data; ND, not determined.

\begin{tabular}{|c|c|c|c|c|c|c|}
\hline Characteristic & 1 & 2 & 3 & 4 & 5 & 6 \\
\hline Cell shape* & SR & $\mathrm{R}$ & $\mathrm{R}$ or $\mathrm{SR}$ & SR & $\mathrm{CR}$ & $\mathrm{R}$ \\
\hline Pigmentation & Beige & Pink to beige & Red to beige & Yellow & $\begin{array}{l}\text { Colourless to } \\
\text { brown }\end{array}$ & $\begin{array}{l}\text { Whitish to } \\
\text { dark red }\end{array}$ \\
\hline Flagella & - & + & - & - & $\mathrm{v} \dagger$ & $\mathrm{V} \ddagger$ \\
\hline \multicolumn{7}{|l|}{ Growth at: } \\
\hline $40{ }^{\circ} \mathrm{C}$ & - & + & + & $\mathrm{v} \S$ & - & - \\
\hline $4^{\circ} \mathrm{C}$ & - & - & vll & $\mathrm{v} \S$ & - & $\mathrm{V}$ \\
\hline pH $10-12$ & + & - & - & - & - & - \\
\hline Bacteriochlorophyll $a$ & - & - & $\mathrm{V}$ & - & - & $-\mathbf{g}$ \\
\hline Nitrate reduction & - & + & - & $\mathrm{V} \#$ & $\mathrm{v} \dagger$ & $\mathrm{V}^{\star *}$ \\
\hline Acid from glucose & + & - & - & - & - & - \\
\hline \multicolumn{7}{|l|}{ Hydrolysis of: } \\
\hline Gelatin & - & - & $\mathrm{v} \dagger \dagger$ & - & $\mathrm{v} \dagger$ & - \\
\hline Aesculin & - & - & ND & $\mathrm{V}$ 杮 & $\mathrm{ND}$ & $\mathrm{V}$ \\
\hline \multicolumn{7}{|c|}{ Major fatty acid composition (\%):§\$ } \\
\hline $\mathrm{C}_{16: 0}$ & 15.3 & 3.8 & $6.2-13.1$ & $7.0-15.0$ & $2.9-3.0$ & - \\
\hline $\mathrm{C}_{18: 1} \omega 7 c$ & 17.3 & 85.3 & $69.4-76.4$ & $31.0-81.2$ & $68.8-84.6$ & $45.0-79.4$ \\
\hline $\mathrm{C}_{16: 0} 2-\mathrm{OH}$ & 27.3 & - & - & - & - & - \\
\hline $\mathrm{C}_{18: 1} 2-\mathrm{OH}$ & 7.7 & - & - & - & - & - \\
\hline 11-Methyl $\mathrm{C}_{18: 1} \omega 7 c$ & 19.6 & 0.7 & $0-2.1$ & $0-8.1$ & - & $0-7.6$ \\
\hline Polar lipids|III & PC, PG, PE & $\mathrm{ND}$ & $\begin{array}{c}\text { PC, PG, } \\
\text { PE, DPG }\end{array}$ & $\mathrm{ND}$ & $\mathrm{ND}$ & $\begin{array}{c}\text { PC, PG, } \\
\text { PE, DPG\#\# }\end{array}$ \\
\hline DNA G $+\mathrm{C}$ content $(\mathrm{mol} \%)$ & 61.7 & 59.0 & $62.9-66$ & $64.7-71.5$ & $57-59$ & $59.1-64.6$ \\
\hline
\end{tabular}

${ }^{*} \mathrm{CR}$, Coccoid to rod-shape; R, rod; SR, short rod.

$\dagger T$. mediterraneus is negative and Thalassobius gelatinovorus is positive for this characteristic.

¥All species are positive except Jannaschia helgolandensis.

$\$$ All species are positive except Oceanicola nanhaiensis.

IIAll species are negative except $R$. tolerans.

SData from J. rubra and J. seosinensis.

\#All species are negative except O. nanhaiensis (weakly positive).

${ }^{*}$ All species are negative except Jannaschia seosinensis.

$\dagger \dagger$ All species are negative except Roseovarius mucosus.

$\ddagger \ddagger O$. granulosus is positive and O. batsensis is negative for this characteristic.

$\$ \$$ For cellular fatty acid analyses, all species except three ( $R$. crassostreae, Roseovarius nubinhibens and J. helgolandensis) were grown on MA. R. crassostreae, R. nubinhibens and J. helgolandensis were grown on SWT (Boettcher et al., 2005), YSST (González et al., 2003) and LBSS (WagnerDöbler et al., 2003) media, respectively.

IIIIDPG, Diphosphatidylglycerol; PC, phosphatidylcholine; PE, phosphatidylethanolamine; PG, phosphatidylglycerol.

ISData from R. tolerans and R. mucosus.

\#\#Data from J. helgolandensis.

Roseobacter clade in the order Rhodobacterales. The type, and only, species is Maritimibacter alkaliphilus.

\section{Description of Maritimibacter alkaliphilus sp. nov.}

Maritimibacter alkaliphilus [al.ka.li'phi.lus. N.L. n. alkali (from the Arabic word al-qaliy) the ashes of saltwort; Gr. adj. philos loving; N.L. masc. adj. alkaliphilus loving alkaline conditions].

In addition to having the traits reported for the genus, colonies on MA are circular, smooth, convex, opaque, beigecoloured and $0.8-1.3 \mathrm{~mm}$ in diameter. Growth occurs at 16-37 ${ }^{\circ} \mathrm{C}$, optimally at $30^{\circ} \mathrm{C}$, but not below $10{ }^{\circ} \mathrm{C}$ or above $42^{\circ} \mathrm{C}$. Growth occurs at $\mathrm{pH} 4-12$ and $0.5-7.5 \% \mathrm{NaCl}$, 
optimally at $\mathrm{pH} 10$ and $2.5-3.0 \% \mathrm{NaCl}$. Oxidase- and catalase-positive. Does not produce indole. Produces acid from glucose utilization. Urea is hydrolysed. Negative for nitrate reduction, arginine dihydrolase, aesculin hydrolysis, gelatin liquefaction and $\beta$-galactosidase. Positive (using API $\mathrm{ZYM}$ ) for alkaline phosphatase, esterase (C4), esterase lipase (C8) and leucine arylamidase. In tests with Biolog GN2 microplates, the following carbon substrates are utilized: dextrin, glycogen, Tweens 40 and 80, maltose, pyruvic acid methyl ester, succinic acid monomethyl ester, acetic acid, $\alpha$ hydroxybutyric acid, $\beta$-hydroxybutyric acid, $\gamma$-hydroxybutyric acid, DL-lactic acid, succinic acid, succinamic acid, Lglutamic acid, inosine and thymidine. The following carbon substrates are not utilized: $\alpha$-cyclodextrin, $N$-acetyl-Dgalactosamine, $\mathrm{N}$-acetyl-D-glucosamine, D-cellobiose, ierythritol, D-fructose, L-fucose, D-galactose, gentiobiose, $\alpha$-D-glucose, myo-inositol, adonitol, L-arabinose, D-arabitol, D-mannitol, $\alpha$-D-lactose, lactulose, D-mannose, D-melibiose, methyl $\beta$-D-glucoside, D-psicose, D-raffinose, Lrhamnose, D-sorbitol, sucrose, D-trehalose, turanose, xylitol, cis-aconitic acid, citric acid, D-galacturonic acid, Dglucosaminic acid, D-galactonic acid, D-gluconic acid, $p$ hydroxyphenylacetic acid, itaconic acid, $\alpha$-ketobutyric acid, $\alpha$-ketovaleric acid, malonic acid, propionic acid, quinic acid, D-saccharic acid, sebacic acid, D-glucuronic acid, formic acid, $\alpha$-ketoglutaric acid, bromosuccinic acid, succinamic acid, glucuronamide, L-alaninamide, D-alanine, L-alanine, L-alanyl glycine, L-asparagine, L-aspartic acid, glycyl Laspartic acid, glycyl L-glutamic acid, L-histidine, hydroxy-Lproline, L-ornithine, L-proline, L-threonine, L-leucine, Lphenylalanine, L-pyroglutamic acid, D-serine, L-serine, DLcarnitine, urocanic acid, $\gamma$-aminobutyric acid, uridine, phenylethylamine, putrescine, 2-aminoethanol, 2,3-butanediol, glycerol, DL- $\alpha$-glycerol phosphate, $\alpha$-D-glucose 1phosphate and D-glucose 6-phosphate. Sensitive to ampicillin $(10 \mu \mathrm{g})$, chloramphenicol $(25 \mu \mathrm{g})$, erythromycin $(15 \mu \mathrm{g})$, gentamicin $(10 \mu \mathrm{g})$, kanamycin $(30 \mu \mathrm{g})$, rifampicin $(50 \mu \mathrm{g})$, streptomycin $(10 \mu \mathrm{g})$, tetracycline $(30 \mu \mathrm{g})$ and vancomycin $(30 \mu \mathrm{g})$ but resistant to penicillin $\mathrm{G}(10 \mu \mathrm{g})$. Cellular fatty acids comprise $\mathrm{C}_{16: 0} 2-\mathrm{OH}(27.3 \%), 11$ methyl $\mathrm{C}_{18: 1} \omega 7 c(19.6 \%), \mathrm{C}_{18: 1} \omega 7 c \quad(17.3 \%), \mathrm{C}_{16: 0}$ (15.3\%), $\mathrm{C}_{18: 1} 2-\mathrm{OH}(7.7 \%)$, cyclo $\mathrm{C}_{19: 0} \omega 8 c(4.8 \%)$, $\mathrm{C}_{16: 1} \omega 7 c$ plus $\mathrm{i}-\mathrm{C}_{15: 0} 2-\mathrm{OH}(2.6 \%), \mathrm{C}_{15: 0} 2-\mathrm{OH}(1.0 \%)$, $\mathrm{C}_{14: 0}(0.7 \%), \mathrm{C}_{10: 0} 3-\mathrm{OH}(0.6 \%), \mathrm{C}_{17: 0}(0.5 \%), \mathrm{C}_{18: 0}$ $(0.5 \%), \mathrm{C}_{17: 0} 2-\mathrm{OH}(0.5 \%), \mathrm{C}_{15: 0}(0.4 \%), \mathrm{C}_{14: 0} 2-\mathrm{OH}$ $(0.3 \%), 10$-methyl $\mathrm{C}_{19: 0}(0.2 \%), \mathrm{C}_{10: 0}(0.2 \%), \mathrm{C}_{18: 0} 2-\mathrm{OH}$ $(0.2 \%), \mathrm{C}_{12: 0}(0.2 \%)$ and $\mathrm{C}_{16: 1} 2-\mathrm{OH}(0.1 \%)$. The DNA $\mathrm{G}+\mathrm{C}$ content of the type strain is $61.7 \mathrm{~mol} \%$ by HPLC and $64.1 \mathrm{~mol} \%$ by genome shotgun sequencing.

The type strain, HTCC $2654^{\mathrm{T}}\left(=\mathrm{KCCM} 42376^{\mathrm{T}}=\mathrm{NBRC}\right.$ $\left.102057^{\mathrm{T}}\right)$, was isolated from Bermuda Atlantic Time Series Station in the western Sargasso Sea, Atlantic Ocean.

\section{Acknowledgements}

We would like to thank the crew of the $R V$ Weatherbird II for their assistance with the collection of seawater samples. We also thank the J. Craig Venter Institute for the genome sequencing, which was supported by a grant from the Gordon and Betty Moore Foundation. We are indebted to Saul Kravitz and Steve Ferriera (J. Craig Venter Institute) and Scott Givan, Joshua Kittner and Kevin Vergin (Oregon State University) for their contributions to the genome sequencing. This study was supported by the 21C Frontier Program of Microbial Genomics and Applications (grant MG05-0102-1-0) from the Ministry of Science and Technology, Republic of Korea, and by the Gordon and Betty Moore Foundation.

\section{References}

Adachi, M., Kanno, T., Okamoto, R., Shinozaki, A., Fujikawa-Adachi, K. \& Nishijima, T. (2004). Jannaschia cystaugens sp. nov., an Alexandrium (Dinophyceae) cyst formation-promoting bacterium from Hiroshima Bay, Japan. Int J Syst Evol Microbiol 54, 1687-1692.

Arahal, D. R., Macián, M. C., Garay, E. \& Pujalte, M. J. (2005). Thalassobius mediterraneus gen. nov., sp. nov., and reclassification of Ruegeria gelatinovorans as Thalassobius gelatinovorus comb. nov. Int J Syst Evol Microbiol 55, 2371-2376.

Biebl, H., Allgaier, M., Lunsdorf, H., Pukall, R., Tindall, B. J. \& Wagner-Dobler, I. (2005). Roseovarius mucosus sp. nov., a member of the Roseobacter clade with trace amounts of bacteriochlorophyll $a$. Int J Syst Evol Microbiol 55, 2377-2383.

Boettcher, K. J., Geaghan, K. K., Maloy, A. P. \& Barber, B. J. (2005). Roseovarius crassostreae sp. nov., a member of the Roseobacter clade and the apparent cause of juvenile oyster disease (JOD) in cultured Eastern oysters. Int J Syst Evol Microbiol 55, 1531-1537.

Button, D. K., Schut, F., Quang, P., Martin, R. \& Robertson, B. (1993). Viability and isolation of marine bacteria by dilution culture: theory, procedures, and initial results. Appl Environ Microbiol 59, 881-891.

Cho, J.-C. \& Giovannoni, S. J. (2003). Parvularcula bermudensis gen. nov., sp. nov., a marine bacterium that forms a deep branch in the $\alpha$ Proteobacteria. Int J Syst Evol Microbiol 53, 1031-1036.

Cho, J.-C. \& Giovannoni, S. J. (2004). Oceanicola granulosus gen. nov., sp. nov. and Oceanicola batsensis sp. nov., poly- $\beta$-hydroxybutyrate-producing marine bacteria in the order 'Rhodobacterales'. Int J Syst Evol Microbiol 54, 1129-1136.

Cho, J. C. \& Giovannoni, S. J. (2006). Pelagibaca bermudensis gen. nov., sp. nov., a novel marine bacterium within the Roseobacter clade in the order Rhodobacterales. Int J Syst Evol Microbiol 56, 855-859.

Choi, D. H., Yi, H., Chun, J. \& Cho, B. C. (2006). Jannaschia seosinensis sp. nov., isolated from hypersaline water of a solar saltern in Korea. Int J Syst Evol Microbiol 56, 45-49.

Cole, J. R., Chai, B., Farris, R. J., Wang, Q., Kulam, S. A., McGarrell, D. M., Garrity, G. M. \& Tiedje, J. M. (2005). The Ribosomal Database Project (RDP-II): sequences and tools for high-throughput rRNA analysis. Nucleic Acids Res 33, D294-296.

Connon, S. A. \& Giovannoni, S. J. (2002). High-throughput methods for culturing microorganisms in very-low-nutrient media yield diverse new marine isolates. Appl Environ Microbiol 68, 3878-3885.

Felsenstein, J. (1981). Evolutionary trees from DNA sequences: a maximum likelihood approach. J Mol Evol 17, 368-376.

Fitch, W. M. (1971). Toward defining the course of evolution: minimum change for a specific tree topology. Syst Zool 20, 406-416.

Giovannoni, S. \& Rappé, M. (2000). Evolution, diversity and molecular ecology of marine prokaryotes. In Microbial Ecology of the Oceans, pp. 47-84. Edited by D. L. Kirchman. New York: Wiley.

González, J. M., Covert, J. S., Whitman, W. B., Henriksen, J. R., Mayer, F., Scharf, B., Schmitt, R., Buchan, A., Fuhrman, J. A. \& other 
authors (2003). Silicibacter pomeroyi sp. nov. and Roseovarius nubinhibens sp. nov., dimethylsulfoniopropionate-demethylating bacteria from marine environments. Int J Syst Evol Microbiol 53, 1261-1269.

Gu, J., Guo, B., Wang, Y. N., Yu, S. L., Inamori, R., Qu, R., Ye, Y. G. \& Wu, X. L. (2007). Oceanicola nanhaiensis sp. nov., isolated from sediments of the South China Sea. Int J Syst Evol Microbiol 57, 157-160.

Kovács, N. (1956). Identification of Pseudomonas pyocyanea by the oxidase reaction. Nature 178, 703.

Labrenz, M., Collins, M. D., Lawson, P. A., Tindall, B. J., Schumann, P. \& Hirsch, P. (1999). Roseovarius tolerans gen. nov., sp. nov., a budding bacterium with variable bacteriochlorophyll $a$ production from hypersaline Ekho Lake. Int J Syst Bacteriol 49, 137-147.

Ludwig, W., Strunk, O., Westram, R., Richter, L., Meier, H., Yadhukumar, Buchner, A., Lai, T., Steppi, S. \& other authors (2004). ARB: a software environment for sequence data. Nucleic Acids Res 32, 1363-1371.

Macián, M. C., Arahal, D. R., Garay, E., Ludwig, W., Schleifer, K. H. \& Pujalte, M. J. (2005). Jannaschia rubra sp. nov., a red-pigmented bacterium isolated from sea water. Int J Syst Evol Microbiol 55, 649-653.

Martens, T., Heidorn, T., Pukall, R., Simon, M., Tindall, B. J. \& Brinkhoff, T. (2006). Reclassification of Roseobacter gallaeciensis Ruiz-Ponte et al. 1998 as Phaeobacter gallaeciensis gen. nov., comb. nov., description of Phaeobacter inhibens sp. nov., reclassification of Ruegeria algicola (Lafay et al. 1995) Uchino et al. 1999 as Marinovum algicola gen. nov., comb. nov., and emended descriptions of the genera Roseobacter, Ruegeria and Leisingera. Int J Syst Evol Microbiol 56, 1293-1304.
Mesbah, M., Premachandran, U. \& Whitman, W. B. (1989). Precise measurement of the $\mathrm{G}+\mathrm{C}$ content of deoxyribonucleic acid by highperformance liquid chromatography. Int J Syst Bacteriol 39, 159-167.

Minnikin, D. E., O’Donnell, A. G., Goodfellow, M., Alderson, G., Athayle, M., Schaal, A. \& Parlett, J. H. (1984). An integrated procedure for the extraction of bacterial isoprenoid quinones and polar lipids. J Microbiol Methods 2, 233-241.

Ostle, A. G. \& Holt, J. G. (1982). Nile blue A as a fluorescent stain for poly- $\beta$-hydroxybutyrate. Appl Environ Microbiol 44, 238-241.

Rüger, H. J. \& Höfle, M. G. (1992). Marine star-shaped-aggregateforming bacteria: Agrobacterium atlanticum sp. nov.; Agrobacterium meteori sp. nov.; Agrobacterium ferrugineum sp. nov., nom. rev.; Agrobacterium gelatinovorum sp. nov., nom. rev.; and Agrobacterium stellulatum sp. nov., nom. rev. Int J Syst Bacteriol 42, 133-143.

Saitou, N. \& Nei, M. (1987). The neighbor-joining method: a new method for reconstructing phylogenetic trees. Mol Biol Evol 4, 406-425.

Smibert, R. M. \& Krieg, N. R. (1994). Phenotypic characterization. In Methods for General and Molecular Microbiology, pp. 611-654. Edited by P. Gerhardt, R. G. E. Murray, W. A. Wood \& N. R. Krieg. Washington, DC: American Society for Microbiology.

Swofford, D. (2002). PAUP*: Phylogenetic analysis using parsimony ( ${ }^{*}$ and other methods), version 4 . Sunderland, MA: Sinauer Associates.

Wagner-Döbler, I., Rheims, H., Felske, A., Pukall, R. \& Tindall, B. J. (2003). Jannaschia helgolandensis gen. nov., sp. nov., a novel abundant member of the marine Roseobacter clade from the North Sea. Int J Syst Evol Microbiol 53, 731-738. 